Texas Southern University

Digital Scholarship @ Texas Southern University

Faculty Publications

$6-1-2020$

\title{
In vitro and in vivo characterization of potent antileishmanial methionine aminopeptidase 1 inhibitors
}

\author{
Felipe Rodriguez \\ The University of Texas at El Paso \\ Sarah F. John \\ Texas Southern University \\ Eva Iniguez \\ The University of Texas at El Paso \\ Sebastian Montalvo \\ The University of Texas at El Paso \\ Karina Michael \\ Texas Southern University
}

See next page for additional authors

Follow this and additional works at: https://digitalscholarship.tsu.edu/facpubs

\section{Recommended Citation}

Rodriguez, Felipe; John, Sarah F.; Iniguez, Eva; Montalvo, Sebastian; Michael, Karina; White, Lyndsey; Liang, Dong; Olaleye, Omonike A.; and Maldonado, Rosa A., "In vitro and in vivo characterization of potent antileishmanial methionine aminopeptidase 1 inhibitors" (2020). Faculty Publications. 73.

https://digitalscholarship.tsu.edu/facpubs/73

This Article is brought to you for free and open access by Digital Scholarship @ Texas Southern University. It has been accepted for inclusion in Faculty Publications by an authorized administrator of Digital Scholarship @ Texas Southern University. For more information, please contact haiying.li@tsu.edu. 


\section{Authors}

Felipe Rodriguez, Sarah F. John, Eva Iniguez, Sebastian Montalvo, Karina Michael, Lyndsey White, Dong Liang, Omonike A. Olaleye, and Rosa A. Maldonado 


\title{
In Vitro and In Vivo Characterization of Potent Antileishmanial Methionine Aminopeptidase 1 Inhibitors
}

\author{
Felipe Rodriguez, ${ }^{\text {a }}$ Sarah F. John, ${ }^{\text {b,d }}$ Eva Iniguez, ${ }^{a}$ Sebastian Montalvo, ${ }^{a}$ Karina Michael, ${ }^{b}$ Lyndsey White, $^{\mathrm{b}, \mathrm{c}}$ Dong Liang, ${ }^{\mathrm{b}}$ \\ Omonike A. Olaleye, ${ }^{\text {b }}$ (D) Rosa A. Maldonado ${ }^{a}$
}

aDepartment of Biological Sciences, Border Biomedical Research Center, The University of Texas at El Paso, El Paso, Texas, USA

bCollege of Pharmacy and Health Sciences, Texas Southern University, Houston, Texas, USA

cCharles River, Worcester, Massachusetts, USA

dHarris Health Systems, Houston, Texas, USA

ABSTRACT Leishmania major is the causative agent of cutaneous leishmaniasis $(\mathrm{CL})$. No human vaccine is available for $\mathrm{CL}$, and current drug regimens present several drawbacks, such as emerging resistance, severe toxicity, medium effectiveness, and/or high cost. Thus, the need for better treatment options against $C L$ is a priority. In the present study, we validate the enzyme methionine aminopeptidase 1 of $L$. major (MetAP1 $1_{\mathrm{Lm}}$ ), a metalloprotease that catalyzes the removal of $\mathrm{N}$-terminal methionine from peptides and proteins, as a chemotherapeutic target against CL infection. The in vitro antileishmanial activities of eight novel MetAP1 inhibitors (OJT001 to OJT008) were investigated. Three compounds, OJT006, OJT007, and OJT008, demonstrated potent antiproliferative effects in macrophages infected with L. major amastigotes and promastigotes at submicromolar concentrations, with no cytotoxicity against host cells. Importantly, the leishmanicidal effect in transgenic L. major promastigotes overexpressing MetAP1 $1_{\mathrm{Lm}}$ was diminished by almost 10 -fold in comparison to the effect in wild-type promastigotes. Furthermore, the in vivo activities of OJT006, OJT007, and OJT008 were investigated in L. major-infected BALB/C mice. In comparison to the footpad parasite load in the control group, OJT008 decreased the footpad parasite load significantly, by $86 \%$, and exhibited no toxicity in treated mice. We propose MetAP1 inhibitor OJT008 as a potential chemotherapeutic candidate against $C L$ infection caused by $L$. major infection.

KEYWORDS Leishmania major, antiparasitic agents, cutaneous leishmaniasis, drug discovery, methionine aminopeptidase 1, molecular parasitology, murine model of cutaneous leishmaniasis, parasitology, target validation

kine he leishmaniases are a complex of infectious diseases caused by more than 20 kinetoplastid protozoan parasites that belong to the Trypanosomatidae family and genus Leishmania. Roughly 12 million people are infected, with an increasing incidence of 2 million per year (1). Moreover, approximately 350 million people are at risk of contracting leishmaniasis in 98 countries across five continents, and it is included in the neglected tropical diseases (NTD) group (1). Clinical manifestations range from nodular and ulcerative skin lesions to progressive mucocutaneous and visceral forms. Cutaneous leishmaniasis (CL) is the predominant human clinical manifestation, and it is characterized by particular localized skin ulcers $(2,3)$. CL is considered a tropical disease. In the Old World, CL is mainly caused by Leishmania aethiopica, Leishmania tropica, and Leishmania major, affecting the Middle East, Mediterranean littoral, Arabian Peninsula, Africa, Near Asia, Indian Subcontinent, and other areas $(4,5)$. In the New World, CL is caused by several species, such as Leishmania mexicana, Leishmania amazonensis, Leishmania venezuelensis, or members of the subgenus Vianna, which includes Leish-

Citation Rodriguez F, John SF, Iniguez E, Montalvo S, Michael K, White L, Liang D, Olaleye OA, Maldonado RA. 2020. In vitro and in vivo characterization of potent antileishmanial methionine aminopeptidase 1 inhibitors. Antimicrob Agents Chemother 64:e01422-19. https://doi.org/10.1128/AAC.01422-19. Copyright $\odot 2020$ American Society for Microbiology. All Rights Reserved. Address correspondence to Omonike A Olaleye, olaleyeoa@TSU.edu, or Rosa A. Maldonado, ramaldonado@utep.edu. Received 20 August 2019 Returned for modification 2 December 2019 Accepted 8 March 2020

Accepted manuscript posted online 16 March 2020

Published 21 May 2020 
mania Vianna braziliensis, L. (V.) guyanensis, L. (V.) panamensis, and L. (V.) peruviana (6). Nonetheless, with increases in travel, military activities, and migration, the disease presents a risk for populations that were previously unaffected, including in the United States, where $C L$ is nowadays considered an emerging concern (7-10).

Currently, there are no available vaccines against leishmaniasis $(11,12)$, and therefore, therapies rely solely upon a reduced number of drugs (13). These drugs, such as the pentavalent antimonials meglumine antimonate and sodium stibogluconate (Glucantime and Pentostam, respectively), miltefosine (Impavido), and liposomal amphotericin B (AmBisome), pose several challenges because of their numerous toxic side effects, high cost, and parenteral administration and the potential emergence of chemoresistant parasites (14). Hence, there is an urgent need for the development of less toxic, more cost-effective, and more therapeutic interventions against leishmaniasis.

Essential enzymes like methionine aminopeptidase (MetAP) have been suggested as promising targets for the development of novel antiparasitic agents. Methionine aminopeptidases are classified into two different types, MetAP1 and MetAP2. The latter contains a 60-amino-acid insertion that distinguishes it from MetAP1 $(15,16)$. MetAP1 is a dinuclear metalloprotease that catalyzes the removal of $\mathrm{N}$-terminal methionine residues from peptides and proteins (17). MetAP1 proteins bind to metal ions like cobalt or zinc for their activity (18), and disruption of MetAP1 impairs proper protein folding, posttranslational modifications, biologic maturation, and translocation of some newly synthesized peptides and proteins within the cell (19). The functionality and importance of MetAP1 has been shown in several organisms, including Escherichia coli, Salmonella enterica serovar Typhimurium, and Mycobacterium tuberculosis, where the knockdown of the MetAP1 gene leads to lethal effects or reduced viability (20-22). In Saccharomyces cerevisiae, the knockdown of MetAP1 leads to slow growth, while the knockdown of MetAP1 and MetAP2 leads to nonviable yeast strains (23). Furthermore, studies have been made of MetAP1b in the protozoan Plasmodium falciparum (PfMetAP1b), one of four types of MetAP found in $P$. falciparum. The observation of antiproliferation effects on several $P$. falciparum strains by highly selective inhibitors of PfMetAP1b has led to the discovery of selective MetAP inhibitors (15). Moreover, MetAP inhibitors have shown promising results against tuberculosis, fungal infections, rheumatic disease, various forms of cancer, malaria, leishmaniasis, and other diseases (15, 22-30). Unlike the protozoan $P$. falciparum, only one methionine aminopeptidase has been discovered in L. major (MetAP1 ${ }_{\mathrm{Lm}}$ ), which has a $50 \%$ sequence similarity with human MetAP1 (MetAP1 of Homo sapiens [HsMetAP1]) and less than 14\% similarity to human MetAP2 (HsMetAP2) (Fig. S1 in the supplemental material). Another report highlighted the potential role of type 2 MetAP in Leishmania donovani (31), and a recent study reported the expression, purification, and characterization of MetAP1 in $L$. donovani, giving more evidence of MetAP1 as a drug target for Leishmania spp. (32). Therefore, we selected methionine aminopeptidase 1 (MetAP1) as a prospective chemotherapeutic target.

Using an integrated whole-cell-based screening and chemogenetic approach, we systematically identified and characterized three novel MetAP $1_{\mathrm{Lm}}$ inhibitors. Previously, a high-throughput screen consisting of a library of 175,000 structurally diverse small molecules was conducted by Olaleye et al. (22). Their study successfully identified lead MetAP1 inhibitors against $M$. tuberculosis (22). As part of the drive to find new antileishmanial treatments, we screened and characterized the antiparasitic activity of these novel MetAP1 inhibitors against $C L$ infection caused by $L$. major in vitro and in an in vivo model. MetAP1 $1_{\mathrm{Lm}}$ inhibitors OJT006, OJT007, and OJT008 showed potent leishmanicidal activity and remarkable selectivity indexes in vitro. More importantly, OJT008 significantly reduced the parasitic load with no evident toxicity in a preclinical in vivo model. These findings suggest MetAP $1_{\mathrm{Lm}}$ as a potential therapeutic target for the development of efficient and nontoxic drugs against CL. MetAP1 can serve as a potential target for the development of novel anti-infective agents to combat the emergence of drug-resistant pathogens. 
TABLE 1 Antiparasitic activities of OJT compounds at $72 \mathrm{~h}$ in L. major promastigotes and cytotoxicities of the compounds to intraperitoneal mouse macrophages

\begin{tabular}{llll}
\hline & \multicolumn{2}{l}{ Value \pm estimated interval for: } & \\
\cline { 2 - 3 } Compound & $10.9 \pm 1.3$ & $\mathrm{CC50}(\boldsymbol{\mu M})^{b}$ & $\mathrm{SA}^{c}$ \\
\hline OJT001 & $11.96 \pm 0.84$ & $\mathrm{NA}$ & $\mathrm{NA}$ \\
OJT002 & $14.36 \pm 0.45$ & $\mathrm{NA}$ & $\mathrm{NA}$ \\
OJT003 & $3.36 \pm 0.13$ & $\mathrm{NA}$ & $\mathrm{NA}$ \\
OJT004 & $6.8 \pm 0.57$ & $\mathrm{NA}$ & $\mathrm{NA}$ \\
OJT005 & $\sim 0.6$ & $\mathrm{NA}$ & $\mathrm{NA}$ \\
OJT006 & $0.38 \pm 0.006$ & $49 \pm 2.34$ & 131.6 \\
OJT007 & $\sim 0.24$ & $\sim 0.68 \pm 2.18$ & 107.05 \\
OJT008 & $\sim 148.1$ & 617.08 \\
\hline
\end{tabular}

${ }^{a} \mathrm{EC}_{50}$, median effective concentration. Measure of antiparasitic activity against $L$. major promastigotes.

${ }^{b} \mathrm{CC}_{50}$, median cytotoxic concentration. Measure of cytotoxicity in mammalian cells (intraperitoneal mouse macrophages [IPФ]).

cSI, selectivity index $\left(\mathrm{CC}_{50} / \mathrm{EC}_{50}\right)$.

${ }^{d} \mathrm{NA}$, not applicable.

\section{RESULTS}

MetAP1 $1_{\text {Lm }}$ inhibitors have potent antileishmanial activities and nontoxic effects in intraperitoneal murine macrophages. The efficacy of theMetAP1 inhibitors tested in this study has been previously demonstrated against the two MetAP1 proteins from M. tuberculosis through a high-throughput screening assay $(22,33)$. Thus, to identify new MetAP inhibitors for the potential treatment of $C L$, we tested eight MetAP1 inhibitors (OJT001, OJT002, OJT003, OJT004, OJT005, OJT006, OJT007, and OJT008) (Table 1 and Fig. S2A) to determine their effectiveness against the promastigote form of $L$. major. First, parasites were incubated with each of the eight inhibitors (OJT001 to OJT008) for 24 or $48 \mathrm{~h}$. The most potent antileishmanial agents found were OJT006, OJT007, and OJT008, exhibiting low 50\% effective concentrations $\left(E_{50}\right)$ of $780 \mathrm{nM}$, $500 \mathrm{nM}$, and $500 \mathrm{nM}$, respectively, after only $24 \mathrm{~h}$ of incubation (Fig. S2C). Interestingly, after 48 and $72 \mathrm{~h}$ of incubation, their antiparasitic effects increased slightly (Table 1 and Fig. S2B and D). Next, the cytotoxic effects of MetAP1 ${ }_{\text {Lm }}$ inhibitors (OJT006, OJT007, and OJT008) were determined by the addition of alamarBlue to intraperitoneal macrophages (IPФ) after 24 or $48 \mathrm{~h}$ of treatment. None of the three inhibitors displayed cytotoxicity against IPФ at concentrations up to $20 \mu \mathrm{M}$ (Table 1 and Fig. S2E and F). Importantly, complete inhibition of extracellular promastigotes of an $L$. major strain expressing firefly luciferase ( $L$. major-luc) was detected at a low concentration of $3.12 \mu \mathrm{M}$. Therefore, a wide window of selectivity (the selectivity indices [SI] were 131.6, 107.05, and 617.08 for OJT006, OJT007, and OJT008, respectively) between parasite and mammalian cell was observed (Table 1).

MetAP1 $1_{\text {Lm }}$ inhibitors reduce the proliferation of $L$. major intracellular amastigotes. The most potent MetAP1 $1_{\mathrm{Lm}}$ inhibitors (OJT006, OJT007, and OJT008) were chosen to further study their effects against intracellular amastigotes proliferated inside IPФ. Since we are interested in the potential antiproliferative properties of these inhibitors, we first incubated L. major-luc-infected BALB/C IPФ for $48 \mathrm{~h}$ with OJT006, OJT007, or OJT008 treatment. We observed that at a concentration of $0.312 \mu \mathrm{M}$, OJT006, OJT007, and OJT008 were able to inhibit the proliferation of intracellular amastigotes by approximately $80 \%, 90 \%$, and $85 \%$, respectively (Fig. 1). Taken together, these results indicated that OJT006, OJT007, and OJT008 have high antileishmanial effects in both the extracellular and intracellular forms of the parasite with no cytotoxicity to mammalian cells. Thus, OJT006, OJT007, and OJT008 were further selected for evaluation in a preclinical in vivo model of CL. The assay $Z$ factor was 0.5 , indicating this is a satisfactory assay.

MetAP1 $1_{\text {Lm }}$ inhibitors act on target. To determine whether our three lead candidates were specific against MetAP1 $1_{\mathrm{Lm}}$, we first treated $1 \times 10^{6}$ transgenic promastigotes/ml (LuCMetAP1 $1_{L m} / p 1 R I H Y G$, a transgenic parasite that simultaneously expresses luciferase and overexpresses MetAP1 $1_{\mathrm{Lm}}$ ) or wild-type parasites for $96 \mathrm{~h}$ with OJT006, 


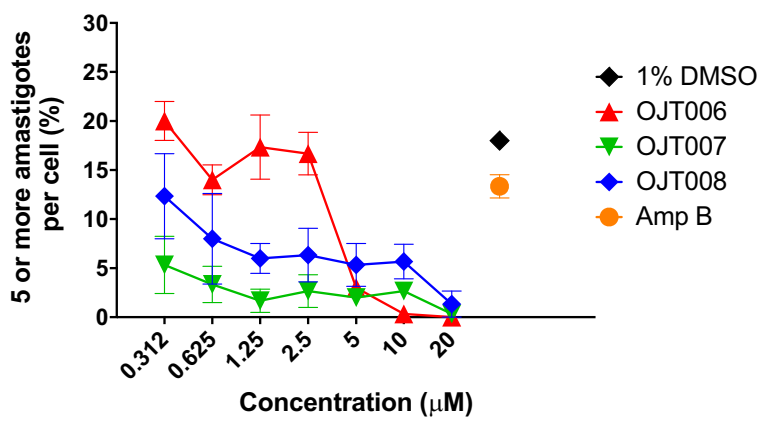

FIG 1 MetAP1 $1_{\text {Lm }}$ inhibitors OJT006, OJT007, and OJT008 reduced the intracellular proliferation of L. major amastigotes. Data from high-content imaging assay ( $\mathrm{HClA}$ ) analysis of intraperitoneal mouse macrophages (IP $\Phi$ ) infected with L. major-luc metacyclic promastigotes and treated with OJT006, OJT007, or OJT008 inhibitor from $0.312 \mu \mathrm{M}$ to $20 \mu \mathrm{M}$ for $48 \mathrm{~h}$ are shown. Controls were treated with $1 \%$ DMSO (drug diluent control) or amphotericin B (Amp B) at $5 \mu \mathrm{M}$ (reference drug; positive control). Data are represented as the percentages (\%) of infected IP $\Phi$ with 5 or more amastigotes per cell. Error bars indicate standard errors of the means (SEM).

OJT007, or OJT008. As expected, the antileishmanial activity of amphotericin B (reference drug; control) was not altered in the transfected $L$ ucMetAP1 ${ }_{L m} / P 1 R I H Y G$ parasites (Fig. 2B). In contrast, increases of more than 10-fold were observed in the $\mathrm{EC}_{50}$ values of OJT006, OJT007, and OJT008 when tested against transfected LucMetAP1 ${ }_{\mathrm{Lm}}$ promastigotes compared to the values for treatment of wild-type L. major-luc (Fig. 2A and B). These data strongly suggest that OJT006, OJT007, and OJT008 successfully inhibited MetAP1 $1_{\mathrm{Lm}}$, acting on target.

Potent in vivo activity of inhibitor $0 J$ J008 against $L$. major infection. The in vivo activities of MetAP1 $1_{\mathrm{Lm}}$ inhibitors OJT006, OJT007, and OJT008 were characterized in L. major-luc-infected BALB/c mice. First, we evaluated the oral drug administration of different formulations by assessing their antiparasitic activities and potential toxicity in mice. Mice treated with a formulation in $70 \%$ deionized (DI) water-30\% polyethylene glycol 400 (PEG 400) showed it to be well tolerated, with no weight loss observed, maintaining the antiparasitic activity of OJT006, OJT007, or OJT008 (Fig. S3A and B). Therefore, this formulation was selected for subsequent experiments. Next, BALB/C mice $(n=5)$ were infected, and after 18 days postinfection (dpi), mice were orally treated at $20 \mathrm{mg} / \mathrm{kg}$ of body weight/day with OJT006, OJT007, or OJT008. After 13 consecutive days of treatment, inhibitors OJT006 and OJT007 were shown to have lower efficacies than OJT008. However, all showed decreases in the lesion sizes in treated mice compared to the effect of the placebo control (Fig. S4). Nevertheless, small lesion sizes were observed through the course of the infection in OJT008-treated mice (Fig. S4). To further study and corroborate the efficacy of OJT008 in the preclinical

A

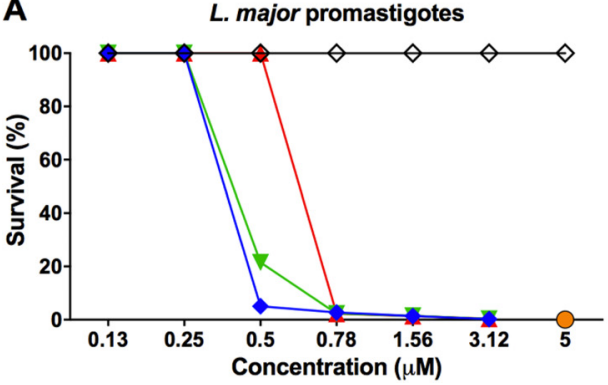

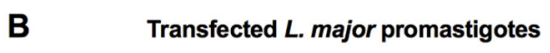

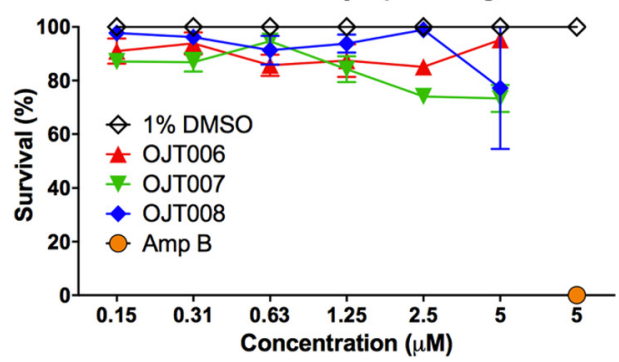

FIG 2 Action of MetAP1 $1_{L m}$ inhibitors OJT006, OJT007, and OJT008 is on target. (A) Data from viability assay of $L$. major-luc promastigotes (wild type) treated with inhibitor OJT006, OJT007, or OJT008 for $96 \mathrm{~h}$ in a concentration range of $0.13 \mu \mathrm{M}$ to $3.12 \mu \mathrm{M}$ are shown. (B) Data from viability assay of transfected (LuCMetAP1 $L \mathrm{Lm} / \mathrm{p} 1 R / H Y G) L$. major promastigotes treated with the OJT006, OJT007, or OJT008 inhibitors in a concentration range of $0.13 \mu \mathrm{M}$ to $3.12 \mu \mathrm{M}$ for $96 \mathrm{~h}$ are shown. Controls were treated with 1\% DMSO (diluent drug control) or amphotericin B (Amp B) at $5 \mu \mathrm{M}$ (reference drug). Error bars indicate SEM. 
A


B

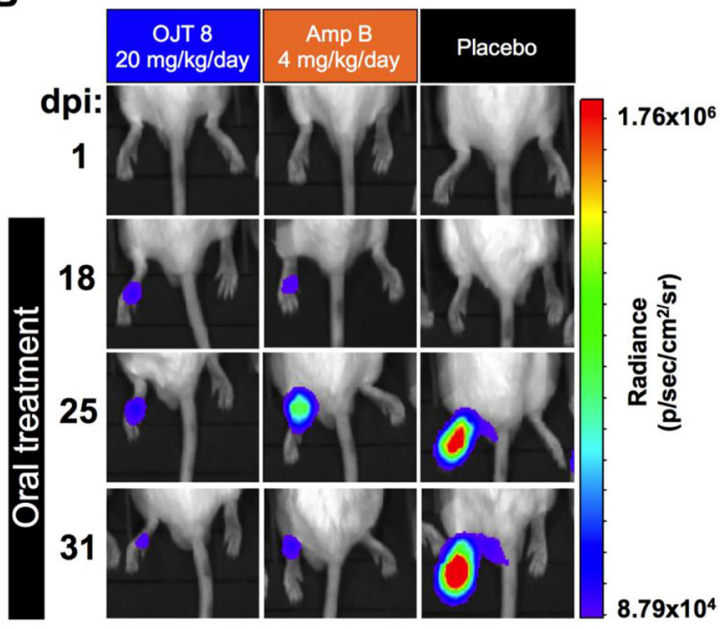

FIG 3 Oral treatment with OJT008 significantly reduced the parasitic burden caused by L. major infection. (A) Quantification of parasite bioluminescence emitted in BALB/C mouse footpads infected with L. major-luc metacyclic promastigotes and treated with $20 \mathrm{mg} / \mathrm{kg} /$ day of OJT008, $4 \mathrm{mg} / \mathrm{kg} /$ day of amphotericin B (Amp B; reference drug group), or placebo (PBS; control group). Two-way ANOVA with Dunnett's multiple-comparison test (compared to placebo group). ${ }^{*}, P<0.05 ;{ }^{* *}$, $P<0.01 ;{ }^{* * *}, P<0.0001$. Error bars indicate SEM. (B) Representative images of in vivo bioluminescence acquired at 1,18, 25, and $31 \mathrm{dpi}$ from L. major-luc-infected BALB/C mice treated with OJT008, Amp B, or placebo. (C) Quantification of parasitic load (parasite equivalents/100 ng) by qPCR at experimental endpoint (31 dpi). One-way ANOVA (compared to placebo; control group). ${ }^{* *}, P<0.01$. Error bars indicate SEM.

model, we decided to follow the infection during the course of treatment, using in vivo bioluminescence imaging. Thus, BALB/c mice $(n=5)$ were infected and treated using the same conditions as before, and images were acquired at 18, 25, and $31 \mathrm{dpi}$ (Fig. $3 \mathrm{~A}$ and B). Similarly to the results for amphotericin B (reference drug), OJT008 significantly $(P<0.0001)$ decreased the parasite's bioluminescence signal (Fig. 3A and B). Furthermore, quantitative PCR (qPCR) was performed to analyze the parasite burden of mice treated with OJT008. As expected, compared to the parasite loads in the placebo group, OJT008-treated mice had a significant $(P<0.01)$ reduction in parasite load, by $86 \%$ (Fig. $3 \mathrm{~B})$. Taken together, these findings suggest that OJT008 successfully reduced and controlled $L$. major infection in a preclinical murine model of $C L$, representing the therapeutic potential of the inhibitor.

The $0 J$ T008 inhibitor is nontoxic in a murine model of CL. Elevated serum levels of alanine aminotransferase (ALT) and aspartate aminotransferase (AST) enzymes are recognized as markers for cardiac and hepatic damage, respectively (34). As observed in the experiments whose results are shown in Fig. 4A and B, serum AST and ALT levels of mice treated with OJT008 were not elevated and were similar to those in the placebo group, indicative of drug safety. These results were further supported by the observation that the mouse weights in the OJT008-treated group were not statistically different from the weights in the placebo-treated control group (Fig. 4C). Additionally, OJT008 caused no changes in the behavior, appetite, waste elimination, appearance, or survival of treated mice compared to these parameters in placebo- and amphotericin B-treated animals (Fig. $4 \mathrm{C}$ ). These results demonstrate the oral safety of the MetAP1 $1_{\mathrm{Lm}}$ inhibitor OJT008 in a preclinical murine model of CL.

\section{DISCUSSION}

Despite the advances in understanding the protozoan parasite L. major, CL continues to cause significant morbidity. The drugs available to treat this disease (i.e., 



FIG 4 OJT008 is nontoxic in vivo. (A and B) Evaluation of systemic toxicity by serum levels of alanine aminotransferase (ALT) (A) and aspartate aminotransferase (AST) (B) in L. major-luc-infected BALB/c mice dosed with $20 \mathrm{mg} / \mathrm{kg} /$ day of OJT008, $4 \mathrm{mg} / \mathrm{kg} /$ day of Amp B, or placebo (PBS). Pooled serum samples were collected at $31 \mathrm{dpi}$ (endpoint). Positive control [C (+)] was provided by the kit's manufacturer (Sigma-Aldrich). Data are represented as units $/ \mathrm{ml}(\mathrm{U} / \mathrm{ml})$. Ordinary one-way ANOVA with Dunnett's multiple-comparison test (compared to positive control). ${ }^{*}, P<0.05$; ${ }^{* *}, P<0.01 ;{ }^{* * *}, P<0.001 ;{ }^{* * * *}, P<0.0001$. (C) Assessment of treatment toxicity by weight change (grams) in $L$. major-luc-infected BALB/c mice treated with $20 \mathrm{mg} / \mathrm{kg} / \mathrm{day}$ of OJT008, Amp B, or placebo (PBS). Two-way ANOVA with Dunnett's multiple-comparison test (compared to PBS group). ${ }^{*}, P<0.05 ;{ }^{* *}, P<0.01 ;{ }^{* * *}, P<0.001 ;{ }^{* * * *}, P<0.0001$. Error bars indicate SEM.

pentavalent antimonials and amphotericin B) are aged, limited in efficacy, and present severe side effects, and drug resistance continues to be reported. Consequently, there is an urgent need for new chemotherapeutic approaches to treat $C L$ (35). Herein, we present data that demonstrate the potential success of novel MetAP1 inhibitors as chemotherapeutic agents against $L$. major infection. MetAP1 is a metalloprotease that removes the $\mathrm{N}$-terminal methionine from proteins and peptides, a process involved in the highly conserved N-terminal methionine excision (NME) pathway (17). Since NME is an essential process in both prokaryotes and eukaryotes $(19,36)$, inhibitors of MetAP have been suggested as novel chemotherapeutic agents against different forms of cancer and bacterial, fungal, and parasitic infections $(22,24-29,33,37)$. Moreover, it has been reported that deletion of MetAP1 in yeast and other eukaryotic cells is detrimental and leads to cell death $(32,38,39)$. Nonetheless, despite the obvious importance of this metalloprotease in L. major, insufficient effort has been taken in exploiting MetAP1 as a drug target for $\mathrm{CL}$.

A screening of 175,000 diverse small molecules conducted by Olaleye et al. (22) led to the discovery of eight potent MetAP1 inhibitors (OJT001 to OJT008). The eight MetAP inhibitors tested belong to four structurally diverse classes of small-molecule compounds affiliated with four structurally distinct chemical classes. Compounds OJT001 to OJT005 are five analogues belonging to the 8-hydroxyquinoline chemical class and are structurally related analogues with the same pharmacophore (26), while compounds OJT006, OJT007, and OJT008 are all structurally different, with diverse pharmacophore classes. OJT006 is a pyridoxal isonicotinoyl compound, OJT007 has the hydrazine-1-ylidene-containing pharmacophore, and OJT008 has the pyrimidin-4amine pharmacore (Table 2). Treatment of $L$. major promastigotes and intracellular amastigotes with inhibitors OJT001 to OJT008 revealed three potent MetAP1 ${ }_{\mathrm{Lm}}$ inhibitors, OJT006, OJT007, and OJT008, with $\mathrm{EC}_{50} \mathrm{~s}$ in the low range of $0.243 \mu \mathrm{M}$ to $0.640 \mu \mathrm{M}$. Interestingly, although the first five hydroxyquinoline compounds (OJT001 to OJT005), with similar pharmacophores, have been reported to have potent activity against $M$. tuberculosis MetAP1 and/or antimycobacterial activity (26), they were not potent against L. major promastigotes, while compounds OJT006, OJT007, and OJT008, with three different novel pharmacophores, showed potent activity against $L$. major promastigotes. These observations suggest the enzyme specificity and selective toxicity of the MetAP inhibitors.

In addition, we have demonstrated that the antiparasitic activity observed for the inhibitors is due to a specific on-target effect by overexpressing MetAP1. We observed a 10 -fold increase in resistance to the antiparasitic activity of the compounds compared to the drug resistance of wild-type L. major-luc. Therefore, we can conclude that since 
TABLE 2 Structural classes of methionine aminopeptidase inhibitors

MetAP inhibitor class

I. 8-Hydroxyquinolines

II. Pyridoxal isonicotinoyls

III. Hydrazin-1-ylidenes
Core structure<smiles></smiles><smiles>O=C(N/N=C/c1c(O)ccc2ccccc12)c1ccncc1</smiles><smiles>Oc1ccccc1/C=N/Nc1ncnc2sc3c(c12)CCCC3</smiles>

IV. Pyrimidin-4-amine

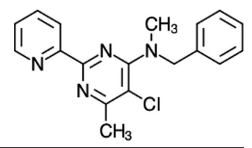

there is an excess of MetAP1 enzyme on the transgenic parasites, a higher concentration of the drugs is required to achieve a similar antiparasitic effect. Similarly, these effects were previously described in an M. tuberculosis model by Olaleye et al. (22). These data provide evidence that the OJT006, OJT007, and OJT008 compounds specifically inhibit MetAP1 from L. major.

Drug accessibility and parenteral administration are two of the main reasons for treatment interruption for leishmaniasis $(13,14)$. Several reports show that patients with conditions ranging from cancer to autoimmune and infectious diseases have an inclination toward oral chemotherapy administration rather than intravenous administration (40-42). Here, we present evidence of potent oral efficacy of MetAP1 inhibitor OJT008 in a preclinical mouse model of CL. OJT008 significantly decreased the parasite load, by $86 \%$, as shown by bioluminescence assay and qPCR. More importantly, OJT008 did not generate adverse or toxic effects in treated infected BALB/c mice, as observed by the low systemic levels of AST and ALT that were measured. Furthermore, these data correlated with no significant weight loss and no behavior changes during the course of treatment. Given these findings, we propose the MetAP1 $1_{\mathrm{Lm}}$ inhibitor OJT008 for further preclinical studies as a novel chemotherapy agent, representing an excellent candidate for the oral treatment of $\mathrm{CL}$.

To summarize, in the present study, we identified and characterized MetAP1 $1_{\mathrm{Lm}}$ as a target for the development of novel antileishmanial drugs. We have discovered three (OJT006, OJT007, and OJT008) novel small-molecule inhibitors of MetAP1 $1_{\mathrm{Lm}}$ with diverse pharmacophores for potential development of agents for $\mathrm{CL}$ treatment. This is the first report of a new pharmacophore targeting L. major-specific MetAP1 (MetAP1 $\left.1_{\text {Lm }}\right)$, in inhibitor OJT008, with significant antileishmanial activity in vitro and in vivo. Further delivery experiments are planned, seeking to improve the antileishmanial activity of OJT008. Our discovery of three new pharmacophores as potent MetAP $1_{\mathrm{Lm}}$ inhibitors makes these pharmacophores and the MetAP $1_{\mathrm{Lm}}$ target an attractive combination for further optimization. In addition, structure-activity relationships and X-ray 
crystallography structure studies will accelerate the rational design and synthesis of more potent MetAP1 $1_{\mathrm{Lm}}$ inhibitors. Furthermore, these inhibitors could be used as chemical probes or tools in the future to better understand the physiologic relevance of MetAP1 $1_{\mathrm{Lm}}$ in $\mathrm{N}$-terminal methionine excision, as well as the essentiality and substrate specificity of this class of enzymes in L. major.

\section{MATERIALS AND METHODS}

Animals and ethics statement. BALB/C mice aged 6 to 8 weeks were bred and maintained in a pathogen-free animal biosafety level 2 (ABSL-2) facility at the Laboratory Animal Resources Center (LARC) at The University of Texas at El Paso (UTEP). All animal studies and procedures were performed so as to minimize the distress and pain for the animals in accordance with the NIH guidance and animal protocol A-201107-1, approved by UTEP's Institutional Animal Care and Use Committee (IACUC).

Culture of Leishmania major. L. major-luc Friedlin clone V1 promastigotes expressing firefly luciferase Lmj-FV1-LUC-TK (L. major strain Friedlin [MHOM/JL/80/Friedlin]) were cultured at $28^{\circ} \mathrm{C}$ in $\mathrm{M} 199$ medium (Sigma-Aldrich) supplemented with hemin, 10\% heat-inactivated fetal bovine serum (iFBS; Gibco), $1 \% 10,000 \mathrm{U} / \mathrm{ml}$ penicillin, $10 \mathrm{mg} / \mathrm{ml}$ streptomycin (Gibco) and treated with $50 \mathrm{ng} / \mathrm{ml} \mathrm{of} \mathrm{strep-}$ tothricin neosulfate (GoldBio) for maintenance of the luciferase (luc) gene.

Culture of mammalian cells. Starch-induced intraperitoneal BALB/c mouse macrophages (IPФ) were obtained as described previously (43) and cultured in Dulbecco's modified Eagle's medium (DMEM; Thermo Fisher Scientific) supplemented with 10\% iFBS (Gibco), 1\% 10,000 U/ml penicillin, and $10 \mathrm{mg} / \mathrm{ml}$ streptomycin (Gibco).

MetAP $1_{\mathrm{Lm}}$ inhibitor formulations. The MetAP1 $1_{\mathrm{Lm}}$ inhibitors were synthesized and three oral formulations were developed by the Olaleye group at Texas Southern University, Houston, TX. However, two of the oral formulations were toxic for the in vivo experiments: formulation one, which consisted of 23\% PEG-400, 75\% glycerin, 0.05\% cremophor EL (all from Sigma-Aldrich), and 0.5\% Labrasol (Gattefosse), and formulation two, which consisted of 33.3\% capryol 90 (Sigma-Aldrich), 33.3\% cremophor EL, and 33.3\% Labrasol. Therefore, for in vivo experiments, inhibitors OJT006, OJT007, and OJT008 were dissolved in a nontoxic oral formulation of $70 \%$ deionized (DI) water and $30 \%$ PEG-400. Stock solutions were dissolved in pure dimethyl sulfoxide (DMSO) at a concentration of $1 \mathrm{mM}$ for in vitro studies.

Luciferase viability assay. MetAP1 $1_{\text {Lm }}$ inhibitors OJT001, OJT002, OJT003, OJT004, OJT005, OJT006, OJT007, and OJT008 were screened against L. major-luc promastigotes. First, parasites at $1 \times 10^{6} / \mathrm{ml}$ were added to 96-well, white, flat-bottom Nunc plates (Thermo Fisher Scientific) together with the inhibitors in a final concentration range from $0.78 \mu \mathrm{M}$ to $100 \mu \mathrm{M}$, in triplicates, followed by $96 \mathrm{~h}$ of incubation at $28^{\circ} \mathrm{C}$. Amphotericin B (Sigma-Aldrich) was used at $5 \mu \mathrm{M}$ as the drug of reference. The efficacies of OJT006, OJT007, and OJT008 were further evaluated. The efficacies of the compounds were assessed by monitoring parasite survival by luciferase activity. The substrate 5 '-fluoroluciferin (ONE-Glo luciferase assay system; Promega) was added according to the manufacturer's protocol, and the signal read in a luminometer (Luminoskan; Thermo Fisher Scientific).

alamarBlue assay of mammalian cell cytotoxicity. The cytotoxicity of OJT006, OJT007, and OJT008 was evaluated using BALB/c mouse IP $\Phi$. First, IP $\Phi$ were harvested and seeded at a density of $1 \times 10 \% / \mathrm{ml}$, followed by $8 \mathrm{~h}$ of incubation. Next, cells were washed, compounds added at an initial concentration of $1 \mathrm{mM}$, and cells serially diluted and incubated for an additional 24 or $48 \mathrm{~h}$ at $37^{\circ} \mathrm{C}, 5 \% \mathrm{CO}_{2}$. The cytotoxicity of the compounds was determined by the addition of alamarBlue (Invitrogen) following the manufacturer's recommendations. Plates were read using a fluorometer (Flouroskan; Thermo Fisher Scientific). The drugs were tested in triplicates, and three independent experiments were performed.

In vitro evaluation of MetAP1 $1_{\mathrm{Lm}}$ inhibitors by high-content imaging assay. Intraperitoneal mouse macrophages were seeded in a BD Falcon 96-well, clear-bottom, black imaging plate and infected with L. major-luc metacyclic promastigotes (44) in a ratio of 10 parasites per macrophage, followed by $24 \mathrm{~h}$ of incubation at $37^{\circ} \mathrm{C}, 5 \% \mathrm{CO}_{2}$. The cells were then washed twice and treated for $48 \mathrm{~h}$ with $\mathrm{MetAP} 1_{\mathrm{Lm}}$ inhibitors (OJT006, OJT007, and OJT008). Each drug was tested in triplicate. To determine the quality of the assay, 10 replicates of each control, 1\% DMSO and amphotericin B, were carried out to calculate the $Z$ factor. Three independent experiments were performed. The procedure was performed as previously described (45). BD Pathway Bioimager 855 was used to determine the percentage of infected cells containing at least 5 intracellular parasites.

Homologous overexpression of MetAP $1_{\mathrm{Lm}}$. The MetAP $1_{\mathrm{Lm}}$ gene was amplified from $L$. major genomic DNA using the oligonucleotides MetAP1 $1_{\mathrm{Lm}}-\mathrm{Xbal}$ sense $\left(5^{\prime}\right.$-TCTAGAGGATCCATGCCCTGCGAAG GCTGCGGC-3') and MetAP $1_{\mathrm{Lm}}$-Xbal antisense (5'-TCTAGAGAATTCTCAGATITGATTCGCTGGGGTCTTCG G-3'). PCR was performed using PCR master mix (Promega), $420 \mathrm{ng}$ of $L$. major genomic DNA, and MetAP $1_{\mathrm{Lm}}$ sense and antisense primers under conditions of denaturation of $5 \mathrm{~min}$ at $95^{\circ} \mathrm{C}$, followed by 40 cycles of $60 \mathrm{~s}$ at $95^{\circ} \mathrm{C}, 60 \mathrm{~s}$ at $68^{\circ} \mathrm{C}$, and $90 \mathrm{~s}$ at $72^{\circ} \mathrm{C}$, and a final 5-min elongation period at $72^{\circ} \mathrm{C}$. The PCR product was purified using the Wizard SV gel and PCR clean-up system (Promega). The amplified MetAP $1_{L m}$ gene was then cloned into the Xbal restriction site of the Leishmania expression vector p1RIHYG. The pIR1HYG expression vector was kindly provided by Stephen M. Beverley at Washington University, St. Louis, MO. The identification of the clone MetAP1 $L m / P 1 R I H Y G$ was confirmed by DNA sequencing (DNA Analysis Core Facility, Border Biomedical Research Center, El Paso, TX). L. major-luc promastigotes were transfected with $25 \mu \mathrm{g}$ of MetAP $1_{L m} / p 1 R I H Y G$. The transfected (LuCMetAP $1_{L m} /$ p1RIHYG) parasites were plated in M199 medium, $0.0005 \%$ hemin, $10 \%$ iFBS (Gibco), $50 \mathrm{ng} / \mathrm{ml}$ streptothricin (GoldBio), $1 \%$ agarose, and incubated at $28^{\circ} \mathrm{C}$. After 10 days, parasite colonies were observed, and an individual colony (clone of parasites) was grown in liquid medium supplemented 
with $16 \mu \mathrm{g} / \mathrm{ml}$ hygromycin. L. major LucMetAP $1_{L m} / p 1 R I H Y G$ transgenic parasites were used to confirm that the activity of MetAP1 $1_{\text {Lm }}$ inhibitors (OJT006, OJT007, and OJT008) was on target by a luciferase viability assay.

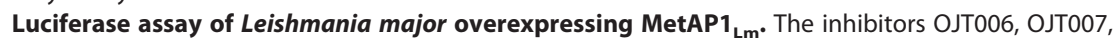

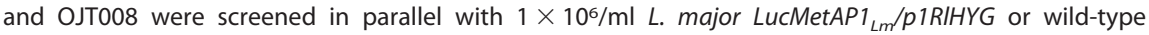
L. major-luc promastigotes for $96 \mathrm{~h}$ at $28^{\circ} \mathrm{C}$. The assay was performed using the same conditions described above for the luciferase viability assay.

In vivo antiparasitic activity of MetAP1 $1_{\mathrm{Lm}}$ inhibitors. Male BALB/c mice (6 to 8 weeks old) were injected in the left hind footpad with $50 \mu \mathrm{l}$ of L. major-luc metacyclic promastigotes in DMEM $\left(1 \times 10^{6} /\right.$ $\mathrm{ml}$ ) after purification by Ficoll step gradient as previously described (44). After 18 days postinfection (dpi), animals were treated orally with $20 \mathrm{mg} / \mathrm{kg} /$ day (100 $\mu \mathrm{l} /$ day) of OJT006, OJT007, or OJT008 or $4 \mathrm{mg} / \mathrm{kg} /$ day intraperitoneally of reference drug amphotericin B (Sigma-Aldrich) for a total of 13 days $(n=5$ mice per group). Infection was monitored by footpad lesion measurements using a digital caliper or by bioluminescence imaging in an IVIS Lumina III in vivo imaging system (Perkin Elmer). Bioluminescence images were acquired at 18, 25, and $31 \mathrm{dpi}$ after administration of $200 \mu \mathrm{l}$ of $150 \mathrm{mg} \mathrm{kg}^{-1} \mathrm{D}$-luciferin in phosphate-buffered saline (PBS; Gold Biotechnology) as previously described (46). After D-luciferin injection, mice were kept conscious for $10 \mathrm{~min}$ to allow luciferin to be metabolized and circulate and then anesthetized with $2.5 \%$ gaseous isoflurane and imaged after 5 additional minutes. Luminescence data were analyzed using Living Image software (Perkin Elmer). Quantification of bioluminescence per footpad is represented as radiance (photons per second per square centimeter per steradian $\left.\left[\mathrm{p} / \mathrm{s} / \mathrm{cm}^{2} / \mathrm{sr}\right]\right)$.

Parasite load by quantitative PCR. At the experimental endpoint, mice were euthanized by $\mathrm{CO}_{2}$ overdose and the infected footpads were harvested from all groups. Genomic DNA was extracted from 20 to $30 \mathrm{mg}$ of tissue using the high pure PCR template preparation kit (Roche), following the manufacture's protocol. Parasite footpad burden was determined by absolute quantification based on a standard DNA curve ranging from 0.5 to $10^{5} \mathrm{~L}$. major parasite equivalents $/ \mathrm{ml}$. A standard curve was produced by extracting DNA from a 20 - to $30-\mathrm{mg}$ tissue fragment spiked with $10^{5} \mathrm{~L}$. major promastigotes. Amplification of a 120-bp fragment from kinetoplastic DNA was performed using $100 \mathrm{nM}$ forward primer (5'-CTTTCTGGTCCTCCGGGTAGG-3), $100 \mathrm{nM}$ reverse primer (5'-CCACCCGGCCCTATITACACCAA-3'), and TaqMan probe (5'-FAM-TTTCGCAGAACGCCCCTACCCGC-TAMRA-3') (47). As an internal control, a linearized pUC57 plasmid containing a sequence from Arabidopsis thaliana was spiked before all DNA extractions as previously described (48). TaqMan chemistry allowed a 2-step temperature cycle. PCR conditions were set at $50^{\circ} \mathrm{C}$ for $2 \mathrm{~min}, 94^{\circ} \mathrm{C}$ for $10 \mathrm{~min}$, followed by 45 cycles at $94^{\circ} \mathrm{C}$ for $15 \mathrm{~s}$ and $55^{\circ} \mathrm{C}$ for $1 \mathrm{~min}$ (47). Samples were run in triplicate in the StepOnePlus real-time PCR System (Applied Biosystems), and parasite equivalents per $100 \mathrm{ng}$ were plotted. All the conditions were followed as previously described (49).

Toxicity monitoring and assessment. Treatment toxicity was evaluated by monitoring mouse weight changes periodically. Weight changes (grams) were normalized by subtracting from the mouse's initial weight. Moreover, blood was collected by cardiac puncture at the endpoint and serum obtained by centrifugation at 2,000 rpm for $10 \mathrm{~min}$. The levels of serum alanine aminotransferase (ALT) and aspartate aminotransferase (AST) enzymes in OJT008-treated mice were measured according to the manufacturer's recommendations (ALT or AST activity kit; Sigma-Aldrich).

Statistical analysis. All data were analyzed and plotted using GraphPad Prism 7.0 (GraphPad Software, Inc., La Jolla, CA). The median lethal dosage $\left(\mathrm{LD}_{50}\right)$, half-maximal cytotoxic concentration $\left(\mathrm{CC}_{50}\right)$, and half-maximal effective concentration $\left(E_{50}\right)$ were calculated. Ordinary one-way analysis of variance (ANOVA) or two-way ANOVA was employed in the statistical analysis. Values were considered significant when $P$ was $<0.05$.

\section{SUPPLEMENTAL MATERIAL}

Supplemental material is available online only.

SUPPLEMENTAL FILE 1, PDF file, 0.6 MB.

\section{ACKNOWLEDGMENTS}

The pIR1HYG expression vector was kindly provided by Stephen M. Beverley at Washington University, St. Louis, MO.

Funding was provided by NIH/ARRA-RTRN grant number U54RR022762 (to R.A.M.), NIGMS/NIH/BUILD grant numbers RL5GM118969, TL4GM118971, and UL1GM118970 (to R.A.M. and O.A.O.), NIH/MARC grant number 2T34GM008048 (to S.M.), and NIH/NIGMS/ RISE grant number R25GM069621-11 (to F.R., E.I., and S.M.).

We are grateful to the following UTEP/BBRC Core Facilities: Biomolecule Analysis (BACF), Cytometry, Screening and Imaging (CSI), and Genomic Analysis (GACF) (supported by NIH/NIMHD grant number 2G12MD007592-21) and Laboratory Animal Resources Center (LARC) at UTEP. This collaborative work was supported in part by Texas Southern University Research Center for Minority Institutions NIH/NIMHD grant number 5G12MD007605. 


\section{REFERENCES}

1. Alvar J, Velez ID, Bern C, Herrero M, Desjeux P, Cano J, Jannin J, den Boer M, WHO Leishmaniasis Control Team. 2012. Leishmaniasis worldwide and global estimates of its incidence. PLoS One 7:e35671. https://do .org/10.1371/journal.pone.0035671.

2. Fortin A, Caridha DP, Leed S, Ngundam F, Sena J, Bosschaerts T, Parriott S, Hickman MR, Hudson TH, Grogl M. 2014. Direct comparison of the efficacy and safety of oral treatments with oleylphosphocholine (OIPC) and miltefosine in a mouse model of L. major cutaneous leishmaniasis. PLoS Negl Trop Dis 8:e3144. https://doi.org/10.1371/ journal.pntd.0003144.

3. Řezníčková E, Popa A, Gucký T, Zatloukal M, Havlíček L, Bazgier V, Berka K, Jorda R, Popa I, Nasereddin A, Jaffe CL, Kryštof V, Strnad M. 2015. 2,6,9-Trisubstituted purines as CRK3 kinase inhibitors with antileishmanial activity in vitro. Bioorg Med Chem Lett 25:2298-2301. https://doi .org/10.1016/j.bmcl.2015.04.030.

4. Du R, Hotez PJ, Al-Salem WS, Acosta-Serrano A. 2016. Old World cutaneous leishmaniasis and refugee crises in the Middle East and North Africa. PLoS Negl Trop Dis 10:e0004545. https://doi.org/10.1371/journal .pntd.0004545.

5. Masmoudi A, Hariz W, Marrekchi S, Amouri M, Turki H. 2013. Old World cutaneous leishmaniasis: diagnosis and treatment. J Dermatol Case Rep 7:31-41. https://doi.org/10.3315/jdcr.2013.1135.

6. Herwaldt BL. 1999. Leishmaniasis. Lancet 354:1191-1199. https://do .org/10.1016/S0140-6736(98)10178-2.

7. Barry MA, Koshelev MV, Sun GS, Grekin SJ, Stager CE, Diwan AH, Wasko CA, Murray KO, Woc-Colburn L. 2014. Cutaneous leishmaniasis in Cuban immigrants to Texas who traveled through the Darien Jungle, Panama. Am J Trop Med Hyg 91:345-347. https://doi.org/10.4269/ajtmh.14-0124.

8. Blum J, Desjeux P, Schwartz E, Beck B, Hatz C. 2004. Treatment of cutaneous leishmaniasis among travellers. J Antimicrob Chemother 53: 158-166. https://doi.org/10.1093/jac/dkh058.

9. Douvoyiannis M, Khromachou T, Byers N, Hargreaves J, Murray HW. 2014. Cutaneous leishmaniasis in North Dakota. Clin Infect Dis 59: e73-e75. https://doi.org/10.1093/cid/ciu386.

10. Wright NA, Davis LE, Aftergut KS, Parrish CA, Cockerell CJ. 2008. Cutaneous leishmaniasis in Texas: a northern spread of endemic areas. J Am Acad Dermatol 58:650-652. https://doi.org/10.1016/j.jaad.2007.11.008.

11. Duthie MS, Reed SG. 2017. Not all antigens are created equally: progress, challenges, and lessons associated with developing a vaccine for leishmaniasis. Clin Vaccine Immunol 24:e00108-17. https://doi.org/10.1128/ CVI.00108-17.

12. Engwerda CR, Matlashewski G. 2015. Development of Leishmania vaccines in the era of visceral leishmaniasis elimination. Trans $\mathrm{R}$ Soc Trop Med Hyg 109:423-424. https://doi.org/10.1093/trstmh/trv039.

13. Nagle AS, Khare $S$, Kumar AB, Supek $F$, Buchynskyy A, Mathison $C J$, Chennamaneni NK, Pendem N, Buckner FS, Gelb MH, Molteni V. 2014. Recent developments in drug discovery for leishmaniasis and human African trypanosomiasis. Chem Rev 114:11305-11347. https://doi.org/10 $1021 / \mathrm{cr} 500365 f$.

14. Croft SL, Coombs GH. 2003. Leishmaniasis-current chemotherapy and recent advances in the search for novel drugs. Trends Parasitol 19: 502-508. https://doi.org/10.1016/j.pt.2003.09.008.

15. Chen X, Chong CR, Shi L, Yoshimoto T, Sullivan DJ, Jr, Liu JO. 2006. Inhibitors of Plasmodium falciparum methionine aminopeptidase $1 \mathrm{~b}$ possess antimalarial activity. Proc Natl Acad Sci U S A 103:14548-14553. https://doi.org/10.1073/pnas.0604101103.

16. Lowther WT, Matthews BW. 2002. Metalloaminopeptidases: common functional themes in disparate structural surroundings. Chem Rev 102: 4581-4608. https://doi.org/10.1021/cr0101757.

17. Lowther WT, Matthews BW. 2000. Structure and function of the methionine aminopeptidases. Biochim Biophys Acta 1477:157-167. https://doi .org/10.1016/s0167-4838(99)00271-x

18. Arfin SM, Kendall RL, Hall L, Weaver LH, Stewart AE, Matthews BW, Bradshaw RA. 1995. Eukaryotic methionyl aminopeptidases: two classes of cobalt-dependent enzymes. Proc Natl Acad Sci U S A 92:7714-7718. https://doi.org/10.1073/pnas.92.17.7714.

19. Giglione C, Boularot A, Meinnel T. 2004. Protein N-terminal methionine excision. Cell Mol Life Sci 61:1455-1474. https://doi.org/10.1007/s00018 -004-3466-8.

20. Chang SY, McGary EC, Chang S. 1989. Methionine aminopeptidase gene of Escherichia coli is essential for cell growth. J Bacteriol 171:4071-4072. https://doi.org/10.1128/jb.171.7.4071-4072.1989.

21. Miller CG, Kukral AM, Miller JL, Movva NR. 1989. pepM is an essential gene in Salmonella typhimurium. J Bacteriol 171:5215-5217. https://doi .org/10.1128/jb.171.9.5215-5217.1989.

22. Olaleye O, Raghunand TR, Bhat $S$, He J, Tyagi S, Lamichhane G, Gu P, Zhou J, Zhang Y, Grosset J, Bishai WR, Liu JO. 2010. Methionine aminopeptidases from Mycobacterium tuberculosis as novel antimycobacterial targets. Chem Biol 17:86-97. https://doi.org/10.1016/j.chembiol.2009.12 .014 .

23. Shim JS, Matsui $Y$, Bhat $S$, Nacev BA, Xu J, Bhang HE, Dhara S, Han KC, Chong CR, Pomper MG, So A, Liu JO. 2010. Effect of nitroxoline on angiogenesis and growth of human bladder cancer. J Natl Cancer Inst 102:1855-1873. https://doi.org/10.1093/jnci/djq457.

24. Trenholme KR, Brown CL, Skinner-Adams TS, Stack C, Lowther J, To J, Robinson MW, Donnelly SM, Dalton JP, Gardiner DL. 2010. Aminopeptidases of malaria parasites: new targets for chemotherapy. Infect Disord Drug Targets 10:217-225. https://doi.org/10.2174/187152610791163363.

25. Musonda CC, Whitlock GA, Witty MJ, Brun R, Kaiser M. 2009. Synthesis and evaluation of 2-pyridyl pyrimidines with in vitro antiplasmodial and antileishmanial activity. Bioorg Med Chem Lett 19:401-405. https://doi .org/10.1016/j.bmcl.2008.11.098.

26. Chen LL, Li J, Li JY, Luo QL, Mao WF, Shen Q, Nan FJ, Ye QZ. 2004. Type I methionine aminopeptidase from Saccharomyces cerevisiae is a potential target for antifungal drug screening. Acta Pharmacol Sin 25: 907-914.

27. Sun J, Li MH, Qian SS, Guo FJ, Dang XF, Wang XM, Xue YR, Zhu HL. 2013. Synthesis and antitumor activity of 1,3,4-oxadiazole possessing 1,4benzodioxan moiety as a novel class of potent methionine aminopeptidase type II inhibitors. Bioorg Med Chem Lett 23:2876-2879. https:// doi.org/10.1016/j.bmcl.2013.03.068

28. Kao RY, Yuen KY, Che CM, Siu FM. 2011. Methionine aminopeptidase as a novel target for antibiotic therapy against Staphylococcus aureus: a proteomic approach. Hong Kong Med J 17(Suppl 2):29-31.

29. Selvakumar P, Lakshmikuttyamma A, Das U, Pati HN, Dimmock JR, Sharma RK. 2009. NC2213: a novel methionine aminopeptidase 2 inhibitor in human colon cancer HT29 cells. Mol Cancer 8:65. https://doi.org/ 10.1186/1476-4598-8-65.

30. Bernier SG, Lazarus DD, Clark E, Doyle B, Labenski MT, Thompson CD Westlin WF, Hannig G. 2004. A methionine aminopeptidase-2 inhibitor, PPI-2458, for the treatment of rheumatoid arthritis. Proc Natl Acad Sci U S A 101:10768-10773. https://doi.org/10.1073/pnas.0404105101.

31. Bhat SY, Dey A, Qureshi IA. 2018. Structural and functional highlights of methionine aminopeptidase 2 from Leishmania donovani. Int J Biol Macromol 115:940-954. https://doi.org/10.1016/j.ijbiomac.2018.04.090.

32. Bhat SY, Jagruthi P, Srinivas A, Arifuddin M, Qureshi IA. 2020. Synthesis and characterization of quinoline-carbaldehyde derivatives as novel inhibitors for leishmanial methionine aminopeptidase 1. Eur J Med Chem 186:111860. https://doi.org/10.1016/j.ejmech.2019.111860.

33. Olaleye O, Raghunand TR, Bhat S, Chong C, Gu P, Zhou J, Zhang Y, Bishai WR, Liu JO. 2011. Characterization of clioquinol and analogues as novel inhibitors of methionine aminopeptidases from Mycobacterium tuberculosis. Tuberculosis (Edinb) 91(Suppl 1):S61-S65. https://doi.org/10 .1016/j.tube.2011.10.012

34. Sousa-Batista AJ, Poletto FS, Philipon C, Guterres SS, Pohlmann AR Rossi-Bergmann B. 2017. Lipid-core nanocapsules increase the oral efficacy of quercetin in cutaneous leishmaniasis. Parasitology 144: 1769-1774. https://doi.org/10.1017/S003118201700097X.

35. de Menezes JP, Guedes CE, Petersen AL, Fraga DB, Veras PS. 2015. Advances in development of new treatment for leishmaniasis. Biomed Res Int 2015:815023. https://doi.org/10.1155/2015/815023.

36. Giglione C, Vallon O, Meinnel T. 2003. Control of protein life-span by $\mathrm{N}$-terminal methionine excision. EMBO J 22:13-23. https://doi.org/10 .1093/emboj/cdg007.

37. Chai SC, Wang WL, Ding DR, Ye QZ. 2011. Growth inhibition of Escherichia coli and methicillin-resistant Staphylococcus aureus by targeting cellular methionine aminopeptidase. Eur J Med Chem 46:3537-3540. https://doi.org/10.1016/j.ejmech.2011.04.056

38. Hu X, Addlagatta A, Lu J, Matthews BW, Liu JO. 2006. Elucidation of the function of type 1 human methionine aminopeptidase during cell cycle 
progression. Proc Natl Acad Sci U S A 103:18148-18153. https://doi.org/ 10.1073/pnas.0608389103.

39. Li X, Chang YH. 1995. Amino-terminal protein processing in Saccharomyces cerevisiae is an essential function that requires two distinct methionine aminopeptidases. Proc Natl Acad Sci U S A 92:12357-12361. https://doi.org/10.1073/pnas.92.26.12357.

40. Sundar S, Mondal D, Rijal S, Bhattacharya S, Ghalib H, Kroeger A, Boelaert M, Desjeux P, Richter-Airijoki H, Harms G. 2008. Implementation research to support the initiative on the elimination of kala azar from Bangladesh, India and Nepal-the challenges for diagnosis and treatment. Trop Med Int Health 13:2-5. https://doi.org/10.1111/j.1365-3156.2007.01974.X.

41. Stewart KD, Johnston JA, Matza LS, Curtis SE, Havel HA, Sweetana SA, Gelhorn HL. 2016. Preference for pharmaceutical formulation and treatment process attributes. Patient Prefer Adherence 10:1385-1399. https://doi.org/ 10.2147/PPA.S101821.

42. Eek D, Krohe M, Mazar I, Horsfield A, Pompilus F, Friebe R, Shields AL. 2016. Patient-reported preferences for oral versus intravenous administration for the treatment of cancer: a review of the literature. Patient Prefer Adherence 10:1609-1621. https://doi.org/10.2147/PPA.S106629.

43. Racoosin EL, Beverley SM. 1997. Leishmania major: promastigotes induce expression of a subset of chemokine genes in murine macrophages. Exp Parasitol 85:283-295. https://doi.org/10.1006/expr.1996 .4139 .

44. Spath GF, Beverley SM. 2001. A lipophosphoglycan-independent method for isolation of infective Leishmania metacyclic promastigotes by density gradient centrifugation. Exp Parasitol 99:97-103. https://doi.org/10.1006/ expr.2001.4656.

45. Nohara LL, Lema C, Bader JO, Aguilera RJ, Almeida IC. 2010. Highcontent imaging for automated determination of host-cell infection rate by the intracellular parasite Trypanosoma cruzi. Parasitol Int 59:565-570. https://doi.org/10.1016/j.parint.2010.07.007.

46. Thalhofer CJ, Graff JW, Love-Homan L, Hickerson SM, Craft N, Beverley SM, Wilson ME. 2010. In vivo imaging of transgenic Leishmania parasites in a live host. J Vis Exp 41:e1980. https://doi.org/10.3791/1980.

47. Mary C, Faraut F, Lascombe L, Dumon H. 2004. Quantification of Leishmania infantum DNA by a real-time PCR assay with high sensitivity. J Clin Microbiol 42:5249-5255. https://doi.org/10.1128/JCM.42.11.5249-5255 2004.

48. Duffy T, Bisio M, Altcheh J, Burgos JM, Diez M, Levin MJ, Favaloro RR, Freilij H, Schijman AG. 2009. Accurate real-time PCR strategy for monitoring bloodstream parasitic loads in Chagas disease patients. PLoS Negl Trop Dis 3:e419. https://doi.org/10.1371/journal.pntd.0000419.

49. Iniguez E, Schocker NS, Subramaniam K, Portillo S, Montoya AL, Al-Salem WS, Torres CL, Rodriguez F, Moreira OC, Acosta-Serrano A, Michael $\mathrm{K}_{\iota}$ Almeida IC, Maldonado RA. 2017. An alpha-Gal-containing neoglycoprotein-based vaccine partially protects against murine cutaneous leishmaniasis caused by Leishmania major. PLoS Negl Trop Dis 11:e006039. https://doi.org/10.1371/journal.pntd.0006039. 